\title{
Potential Neuroregenerative and Neuroprotective Effects of Uridine/Choline-Enriched Multinutrient Dietary Intervention for Mild Cognitive Impairment: A Narrative Review
}

\author{
Barry S. Baumel (D) - P. Murali Doraiswamy - Marwan Sabbagh • \\ Richard Wurtman
}

Received: November 2, 2020 / Accepted: December 2, 2020 / Published online: December 26, 2020

(C) The Author(s) 2020

\begin{abstract}
In mild cognitive impairment (MCI) due to Alzheimer disease (AD), also known as prodromal $\mathrm{AD}$, there is evidence for a pathologic shortage of uridine, choline, and docosahexaenoic acid [DHA]), which are key nutrients needed by the brain. Preclinical and clinical evidence shows the importance of nutrient bioavailability to support the development and maintenance of brain structure and function in MCI and AD. Availability of key nutrients is limited in MCI, creating a distinct nutritional need for uridine, choline, and DHA. Evidence suggests that metabolic derangements associated with ageing and disease-related pathology can affect the body's ability to generate and
\end{abstract}

B. S. Baumel ( $\square)$

Department of Neurology, Miller School of Medicine, University of Miami, Miami, FL, USA e-mail: b.baumel@miami.edu

\section{P. M. Doraiswamy}

Department of Psychiatry and Behavioral Sciences, Duke University School of Medicine, Durham, NC, USA

M. Sabbagh

Lou Ruvo Center for Brain Health, Cleveland Clinic, Las Vegas, NV, USA

R. Wurtman

Department of Brain and Cognitive Sciences,

Massachusetts Institute of Technology, Cambridge, MA, USA utilize nutrients. This is reflected in lower levels of nutrients measured in the plasma and brains of individuals with $\mathrm{MCI}$ and $\mathrm{AD}$ dementia, and progressive loss of cognitive performance. The uridine shortage cannot be corrected by normal diet, making uridine a conditionally essential nutrient in affected individuals. It is also challenging to correct the choline shortfall through diet alone, because brain uptake from the plasma significantly decreases with ageing. There is no strong evidence to support the use of single-agent supplements in the management of MCI due to AD. As uridine and choline work synergistically with DHA to increase phosphatidylcholine formation, there is a compelling rationale to combine these nutrients. A multinutrient enriched with uridine, choline, and DHA developed to support brain function has been evaluated in randomized controlled trials covering a spectrum of dementia from MCI to moderate AD. A randomized controlled trial in subjects with prodromal $\mathrm{AD}$ showed that multinutrient intervention slowed brain atrophy and improved some measures of cognition. Based on the available clinical evidence, nutritional intervention should be considered as a part of the approach to the management of individuals with MCI due to AD, including adherence to a healthy, balanced diet, and consideration of evidence-based multinutrient supplements. 
Keywords: Alzheimer disease; Choline; Docosahexaenoic acid; Mild cognitive impairment; Multinutrient; Uridine

\section{KEY SUMMARY POINTS}

\section{DIGITAL FEATURES}

This article is published with digital features, including a summary slide, to facilitate understanding of the article. To view digital features for this article go to https://doi.org/10.6084/ m9.figshare.13312946.

\section{INTRODUCTION}

According to the diagnostic criteria developed by the National Institute on Aging-Alzheimer's Association (NIA-AA) [1], mild cognitive impairment (MCI) may be differentiated from dementia by maintenance of functional

independence and the absence of significant impairment in social or occupational functions [2]. The NIA-AA criteria also define 'MCI due to Alzheimer's disease (AD)' to describe individuals who are symptomatic and have evidence of $\mathrm{AD}$ pathology prior to a diagnosis of dementia [1]. Individuals with MCI due to $\mathrm{AD}$ (the prodromal stage of $\mathrm{AD}$, as defined using the International Working Group [IWG]-1 criteria [3]) are on a clinical pathway towards overt dementia. These individuals typically have mild cognitive and functional impairments, and pathologic changes shown by biomarkers [2-4]. Disease progression from MCI to $\mathrm{AD}$ is characterized by increasingly debilitating memory loss and cognitive impairment [5]. Worsening clinical symptoms correlate with a net loss of synapses [6], resulting from increased breakdown of existing synapses and reduced formation of new synapses [7]. These ominous pathophysiological changes begin even before the disease manifests clinically [6], and signal a need for early intervention $[8,9]$. In $\mathrm{MCI}$ due to $\mathrm{AD}$, there is an unmet medical need to stimulate the process of synapse formation (neuroregeneration) and to reduce neuronal loss and/or mitigate the adverse effects of neuronal breakdown products (neuroprotection) [10].

Pharmacologic approaches targeting synaptic dysfunction have been reviewed by other authors [10-14]. We wished to consider the challenge from a different perspective, looking at the importance of nutrient substrates involved in the metabolic pathways leading to synaptogenesis [15]. Evidence suggests that substrates needed simultaneously for the Kennedy/phosphatidylcholine (PC) pathway [16], namely uridine, choline, and docosahexaenoic acid (DHA), have important neuroregenerative and neuroprotective functions in the central nervous system (CNS) $[17,18]$. In this review, we examine the evidence for a disease-related shortage in the bioavailability of uridine, choline, and DHA, and evaluate the potential for increasing brain levels of these nutrients to improve long-term outcomes in MCI due to AD. Other authors have highlighted the potential of dietary and nutritional intervention for MCI due to $\mathrm{AD}$, while noting the limited evidence supporting effectiveness, particularly for single- 
agent nutrients [19-22]. It is not our intention to recapitulate previous comprehensive reviews; instead, we focus on uridine and choline in MCI due to $\mathrm{AD}$, and highlight the particular challenge of correcting the shortfall in uridine availability.

\section{METHODS}

We searched the PubMed database in May 2020 using various combinations of the following search terms: 'mild cognitive impairment', 'Alzheimer's disease', 'prodromal Alzheimer's disease', 'uridine', 'choline', and 'docosahexaenoic acid'. The primary focus of the search was to identify studies in human subjects with MCI. In addition, we included nonclinical studies investigating the effects of nutrient interventions on neuronal structure and function. We selected the most relevant articles based on our knowledge of the field. The specific objectives of the literature review were to assess evidence showing changes in the levels of uridine and choline in patients with MCI and $\mathrm{AD}$; the neurologic consequences of nutrient shortages; the possible neuroregenerative and neuroprotective effects of increasing nutrient supply; and outcomes data from controlled clinical trials investigating single or multinutrient supplements in patients with MCI. We considered the available evidence supporting the hypothesis that a shortage of specific nutrients leads to an inability to increase neuronal membrane formation to counteract the net loss of synapses occurring in MCI.

\section{Compliance with Ethics Guidelines}

This article is based on previously conducted studies and does not contain any new studies with human participants or animals performed by any of the authors. All clinical trials cited in this review provided ethical declarations in the original publications and were conducted in compliance with the Declaration of Helsinki.

\section{URIDINE AND CHOLINE ARE CRUCIAL MOLECULES FOR BRAIN FUNCTION}

\section{Uridine}

Uridine is the major form of pyrimidine nucleoside taken up by the brain, where it is used in nucleic acids and for the synthesis of membrane constituents [18]. In addition, uridine is a biologically active molecule in the brain with apparent roles in several CNS functions including memory and neuronal plasticity (reviewed in [18]). The effects of uridine on brain structures and functions appear to be mediated by its effects in promoting neuronal membrane formation and through interactions with specific uridine-nucleotide receptors (brain P2Y2 receptors) that control neuronal differentiation $[15,18,23]$. It has been suggested that activation of $\mathrm{P} 2 \mathrm{Y} 2$ receptors by uridine triphosphate (UTP), released as a neurotransmitter from presynaptic terminals [24], could have a neuroprotective effect in neurodegenerative diseases such as AD [25]. Furthermore, UTP may be converted to cytidine triphosphate (CTP), which is a key intermediate used in the Kennedy cycle to generate PC for the synthesis of neuronal membranes (Fig. 1) [15]. Considering the important role that uridine has in brain structure and functions, it is not surprising that shortages in uridine supply can lead to neurological symptoms [26].

\section{Choline and DHA}

Choline is an essential micronutrient that is required for normal brain development and cognitive functions throughout life [27, 28]. Choline modulates the expression of key genes related to memory, learning, and cognitive functions via epigenetic mechanisms [27]. The central importance of the cholinergic system in the pathophysiology of dementia has been reviewed extensively [29]. Choline is a limiting precursor of the neurotransmitter acetylcholine (ACh) [27]. Cholinergic deficit is a hallmark of $\operatorname{AD}[29,30]$, and changes may be evident from the early stages of disease [31]. However, in MCI 


\section{Kennedy pathway}

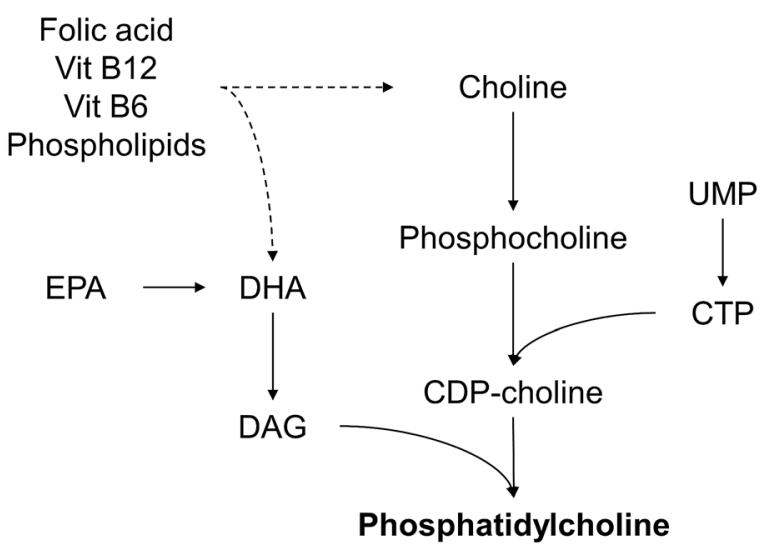

Fig. 1 Pathways of phosphatidylcholine synthesis. EPA eicosapentaenoic acid, $D H A$ docosahexaenoic acid, $D A G$ diacylglycerol, UMP uridine monophosphate, CTP

and early $\mathrm{AD}$, cognitive deficits are not directly associated with cholinergic system loss, and research suggests that compensatory upregulation of choline acetyltransferase (ChAT) activity could be important in mitigating the progression of MCI to AD [32].

Drug therapy to increase cholinergic neurotransmission is standard in the symptomatic management of $\mathrm{AD}$ [33] and may be used in some individuals with MCI, despite a lack of strong evidence [5]. An alternative approach to counter deficits in the cholinergic system could be to improve the supply of choline and other substrates. As a key substrate of metabolic pathways (Kennedy and phosphatidylethanolamine $\mathrm{N}$-methyltransferase [PEMT]) involved in the generation of PC $[34,35]$, choline is needed, together with DHA and uridine, for the synthesis of neuronal membranes (Fig. 1) [17].

Phospholipid abnormalities, consistently affecting PC species with five or six double bonds, for example PC-DHA [28], are well documented in the brains [36-50] and cerebrospinal fluid (CSF) [51-53] of patients with $\mathrm{AD}$, and these changes are reflected in the
PEMT pathway

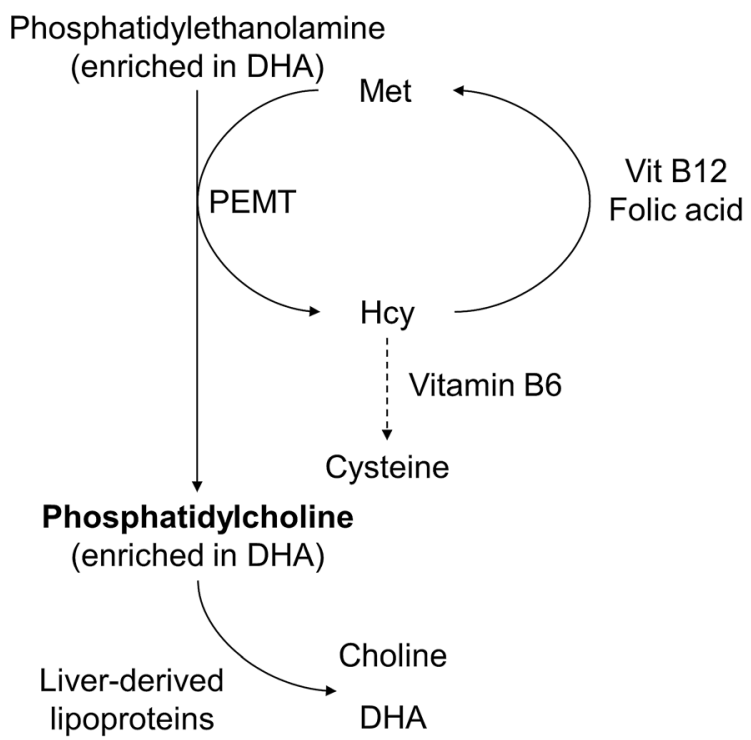

cytidine triphosphate, $C D P$-choline cytidine diphosphatecholine, Hcy homocysteine, Met methionine, UMP uridine monophosphate, Vit vitamin

plasma [54-70]. Disturbed phospholipid metabolism is evident early in the disease process and is observed in individuals with MCI $[49,50,68,71-73]$. Studies in patients with AD have shown lower levels of PC-DHA, which is associated with faster cognitive decline than in control subjects [74-76], whereas the highest level of plasma PC-DHA was associated with a significant reduction in the risk of developing all-cause dementia in the Framingham Heart Study [77].

\section{AVAILABILITY OF KEY NUTRIENTS IS LIMITED IN MCI, CREATING A DISTINCT NUTRITIONAL NEED FOR URIDINE AND CHOLINE}

Previously, two systematic meta-analyses have shown that patients with AD have significantly lower plasma and brain levels of specific nutrients, including DHA and choline-containing lipids, compared with age-matched controls with normal cognitive function [78, 79]. Studies have shown that levels of uridine are lower in 
the plasma and/or brains of patients with $\mathrm{AD}$ compared with age-matched healthy controls [80-88]. These changes occur in very mild AD even in the absence of protein/energy malnutrition [82]. In addition, metabolomic analyses have shown that increased brain cysteine levels associated with decreased uridine can characterize mild $\mathrm{AD}[80]$. The authors suggested that a reduction in uridine in the CSF of patients with $\mathrm{AD}$ could mediate reduced synaptic plasticity and neuronal deficits [80].

Metabolomic analyses have also shown significant changes in neurotransmitter metabolism in the ACh pathway in CSF from individuals with $\mathrm{AD}$ [88], and in choline and tryptophan pathways in early AD [89]. High levels of homocysteine are observed in patients with $\mathrm{AD}$, which can impair choline synthesis by interfering with the activity of the PEMT pathway [74]. Therefore, metabolic disturbances affecting the PEMT pathway can reduce the syntheses of PC and ACh.

One cross-sectional study examined levels of uridine, choline, folate, homocysteine, and other substrates in the blood and CSF of 148 individuals with MCI (age $66 \pm 8$ years, 37\% female, mini-mental state examination [MMSE] 26.7) compared with 148 healthy, matched controls (age $59 \pm 8$ years, $38 \%$ female, MMSE 28.3) [83]. The analysis showed that subjects with MCI had significantly lower levels of uridine than controls both in the blood (mean \pm standard deviation $3.64 \pm 1.25$ vs $4.08 \pm 1.50$, respectively; $P<0.05)$ and in the CSF $(2.90 \pm 0.60$ vs $3.07 \pm 0.59$, respectively; $P<0.05)$. Subjects with MCI also had lower blood and CSF folate, and higher CSF homocysteine concentrations than control subjects (all $P<0.05$ ) [83]. Blood and CSF levels of choline were not significantly different between MCI and control groups [83]. The study also included a cohort of 150 patients with AD (age $66 \pm 7$ years, $37 \%$ female, MMSE 20.5). While patients with $\mathrm{AD}$ had lower levels of CSF uridine and blood choline (and higher CSF homocysteine) than control subjects, the study showed no differences in blood and CSF levels of these nutrients between subjects with MCI and those with $\mathrm{AD}$ [83]. This finding supports the notion that changes in nutrient status start early in the course of $\mathrm{AD}$ [82]. The study also showed that blood levels of uridine, choline, betaine, folate, and homocysteine positively correlated with CSF levels in all groups [83]. However, the authors noted weaker correlations between blood and CSF levels of uridine and folate in subjects with AD than in control subjects, which they suggested could indicate decreased uptake into the brain [83]. The brain cannot synthesize choline, and plasma choline does not freely cross the blood-brain barrier [27]. The availability of choline to the brain may therefore be restricted by age-related changes in transport of plasma choline across the blood-brain barrier [27, 90, 91].

From a clinical perspective, it is important to know whether shortages in these key nutrients correlate with the severity of memory loss and cognitive impairment. A cross-sectional study of elderly subjects, aged 70-74 years, selected independently of their cognitive status, showed that low levels of choline in the plasma are associated with poor cognitive performance [92]. A National Health and Nutrition Examination Survey (NHANES) study found that inadequate intake of micronutrients including choline was significantly associated with lower working memory performance in healthy elderly subjects (aged $\geq 60$ years) [93]. A prospective study involving a total of 551 individuals with subjective cognitive decline (SCD; $n=219$, age $61 \pm 8$ years, $47 \%$ female), MCI ( $n=135$, age $66 \pm 8$ years, $40 \%$ female), or ADtype dementia ( $n=197$, age $67 \pm 8$ years, $50 \%$ female) looked at potential nutritional markers associated with clinical progression (defined as progression of SCD to MCI or dementia, progression of MCI to dementia, an increase of $\geq 1$ point on clinical dementia rating scale or admission to a nursing home or death in subjects with $\mathrm{AD}$, or self-reported progression of cognitive symptoms in all groups) [94]. Clinical progression was observed in $25(11 \%)$ subjects with SCD, in 45 (33\%) with MCI, and in 100 (51\%) with AD. Preliminary results showed that clinical progression was associated with higher levels of low-density lipoprotein cholesterol in subjects with SCD (hazard ratio [HR] 1.92; 95\% confidence intervals [CI] 1.05-3.52), and with lower levels of uridine in subjects with $\mathrm{AD}$ (HR 
0.78; 95\% CI 0.62-0.99). Lower levels of uridine were also associated with clinical progression in subjects with a positive amyloid test. Based on these findings, the authors recommended targeting uridine and cholesterol levels in individuals with cognitive decline [94].

In summary, the evidence suggests that metabolic derangements associated with ageing and disease pathology can affect the ability of the body to utilize nutrients and generate brain synapses $[80,87,88]$. This is reflected in lower levels of the nutrients as measured in the blood and brains of individuals with MCI and very mild $\mathrm{AD}$, and progressive loss of cognitive performance.

\section{INCREASING URIDINE AND CHOLINE AVAILABILITY PROMOTES NEUROREGENERATION AND IS NEUROPROTECTIVE}

The metabolic pathways involved in the conversion of uridine to UTP and subsequently to CTP for use in the PC pathway depend on lowaffinity enzymes; consequently, providing the brain with uridine will increase the formation of PC [17]. Preclinical experiments have shown that administration of uridine with other key substrates (choline and DHA) stimulates neuroregeneration (reviewed in [95]), increasing the production of synaptic proteins [96-98], the formation of neurites and synapses [98-102], and the levels of neurotransmission [96, 103-105], which in turn may lead to improvements in memory performance [103, 106-109]. Preclinical experiments have also shown that uridine administration may provide neuroprotection [95], evidenced by reducing Abeta production and plaque formation $[103,110]$, and diminishing neurodegeneration [103, 106, 107, 110]. It is important to note that these neuroprotective effects were observed by administering uridine with other nutrients including choline and DHA. For example, administering a multinutrient containing uridine, choline, and DHA was shown to protect the cholinergic system against
Abeta42-induced toxicity in rats [103] and to reduce $\mathrm{AD}$-like pathology in AbetaPP/PS1 mice [110].

There is evidence from the clinical setting showing that uridine administration may have positive effects on cognitive functions. A controlled study in 17 healthy volunteers showed that administration of uridine increases brain membrane phospholipid precursors (measured using 31-phosphorus magnetic resonance spectroscopy [MRS]) [111]. Another MRS study in healthy volunteers $(n=16)$ showed that administration of cytidine diphosphate-choline (CDP-choline) also affects phospholipid membrane turnover and may increase the availability of phospholipid membrane components needed to synthesize and maintain cell membranes [112].

There is only limited evidence from clinical studies to show that administration of uridine or choline improves cognitive performance. A small clinical trial $(n=12)$ showed that administration of CDP-choline (which increases uridine levels in the brain [113]) improved performance in individuals with relatively inefficient memory [114]. A population-based study in 1391 subjects (aged 36-83 years) free from dementia showed that concurrent choline intake was positively correlated with cognitive function tests and inversely correlated with white-matter hyperintensity volume [115]. Another population study $(n=2497$ dementiafree men aged 42-60 years) showed that higher intake of PC was associated with lower risk of incident dementia and better cognitive performance [116]. In the dementia setting, a randomized controlled trial showed that choline alfoscerate decreased cognitive impairment due to mild to moderate $\mathrm{AD}$ [117].

\section{THE NUTRITIONAL NEED FOR URIDINE AND CHOLINE IN MCI CANNOT BE MET WITH A NORMAL DIET OR SINGLE SUPPLEMENTS}

Long-term adherence to a healthy diet appears to support cognitive function in ageing 
individuals at risk for dementia [20, 118, 119]. Recent research suggests that preventive strategies including diet, exercise, cognitive training, and vascular risk monitoring may be more effective if started early, before pronounced structural brain changes develop [120].

McGrattan and colleagues performed a systematic review of randomized controlled trials of dietary interventions (dietary pattern or supplements) in subjects with any form of MCI diagnosed by a physician according to internationally accepted criteria [121]. The literature search done in June 2016 identified 16 trials, including one using a multinutrient intervention containing uridine, choline, and DHA [122]. The authors reported inconsistent findings among the heterogenous studies, which overall did not provide clear evidence to support any particular dietary intervention to improve cognitive function in MCI, or evidence of a significant effect on progression from MCI to dementia [123]. Our literature search did not identify any more recent clinical studies of uridine or choline supplementation in subjects diagnosed with MCI due to AD.

The apparent nutritional need in MCI due to AD cannot be addressed simply by modifying the normal diet or administering multivitamin/ mineral supplements, as these may unnecessarily increase the intake of other nutrients associated with increased risk of dementia (e.g. cholesterol, trans fatty acids, saturated fat, and vitamin A) [124, 125]. Dietary modifications to address shortages of uridine and choline in individuals with MCI due to $\mathrm{AD}$ appear to be particularly challenging. Uridine obtained from dietary sources is unavailable to the adult brain (due to degradation by the liver) [126], while food substances purported to increase uridine levels, such as beer [127], are impractical and potentially harmful. As an essential nutrient, choline must be obtained from the diet. Although available from many dietary sources, it is estimated that up to $90 \%$ of Americans consume below the adequate intake for choline [128].

Dietary supplements have been suggested to increase levels of specific nutrients in individuals with MCI and AD [28, 46, 113, 129, 130]; however, to date, nutrient intervention studies have shown that while single-agent supplements are effective in elevating plasma levels, they generally fail to demonstrate clinical benefits [131-134]. We found only limited evidence from randomized controlled clinical trials to support single-agent supplementation with uridine, choline (or CDP-choline), or DHA in MCI due to AD or probable AD [121, 135-138]. As uridine and choline work synergistically with DHA to increase PC formation, there is a compelling rationale for combining these nutrients [139].

\section{CLINICAL EVIDENCE FOR URIDINE- AND CHOLINE-ENRICHED MULTINUTRITIONAL INTERVENTION IN MCI DUE TO AD}

A specific uridine-, choline-, and DHA-enriched multinutrient (Souvenaid; Nutricia) has been developed to support synapse formation in patients with $\mathrm{AD}$ and MCI due to $\mathrm{AD}$ (Table 1). The first randomized controlled clinical trials of this multinutrient were conducted in patients with mild-moderate $\mathrm{AD}$ because of the high medical and nutritional needs in this population [140-143]. An early trial of the product in 527 patients with mild-moderate AD dementia (MMSE 19.5, receiving drug therapy for AD) showed no significant cognitive improvements over a 24-week intervention period [143]. The authors speculated that patients with moderate $\mathrm{AD}$ may have progressed to such an extent that neuronal damage and synaptic dysfunction was irreversible and not responsive to either pharmacologic or non-pharmacologic interventions. They suggested that the potential to benefit from multinutritional interventions to increase synaptogenesis may be limited in moderate $\mathrm{AD}$ compared with mild $\mathrm{AD}$ because of the higher levels of neurodegeneration [143]. Two further clinical trials showed that the multinutrient was associated with a statistically significant improvement in memory in patients with mild and very mild AD dementia (MMSE 23.9 [141] and MMSE 25 [142]) over 12-48 weeks, respectively [140-142]. Since the data implied effects were most likely to be achieved at the early end 


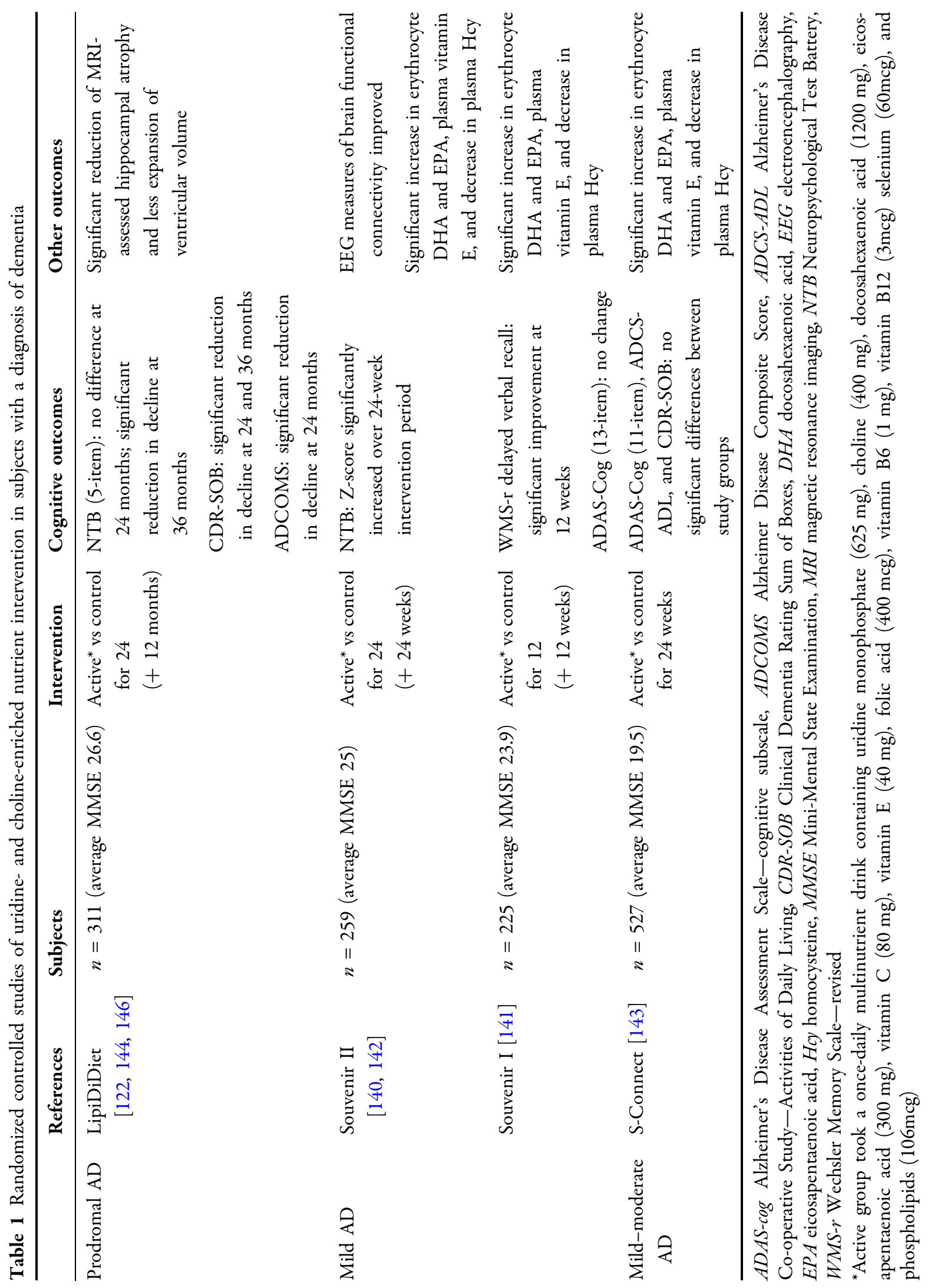


of the $\mathrm{AD}$ spectrum, the LipiDiDiet study was designed to test multinutrient intervention in patients with $\mathrm{MCI}$ due to $\mathrm{AD}$ (prodromal $\mathrm{AD}$ ) [122].

The LipiDiDiet study was a randomized, controlled, double-blind, parallel-group multicentre trial in 311 subjects with MCI due to AD (MMSE 26.6) [122], as defined by episodic memory disorder and evidence for underlying AD pathology [3]. Subjects were randomly assigned (1:1) to receive Souvenaid or a matched control product, taken every day for 24 months [122], with the option to enter an extension study period [144]. The primary endpoint was a change in a neuropsychological test battery (NTB; composite $z$-score based on Consortium to Establish a Registry for Alzheimer's disease [CERAD] 10-word list learning immediate recall, CERAD 10-word delayed recall, CERAD 10-word recognition, category fluency, and letter-digit substitution test). The authors noted that cognitive decline in the LipiDiDiet study population was much lower than expected in both groups, so the primary endpoint was inadequately powered; no significant effect on the primary endpoint was found after 24 months. Interestingly, significant effects were observed for secondary endpoints, including Clinical Dementia Rating scale-Sum of Boxes (CDR-SOB) and Alzheimer Disease Composite Score (ADCOMS). The ADCOMS scale provides a composite clinical outcome measure and was designed for use in trials in MCI due to AD and mild AD dementia [145]. A post hoc analysis of data from the LipiDiDiet study showed that during the 24-month intervention period, worsening on ADCOMS was $36 \%$ less in the multinutrient group than in the control group; estimated mean treatment difference $-0.048 \quad(95 \%$ CI -0.090 to -0.007 ; $P=0.023)$ [146]. Magnetic resonance imaging (MRI) analyses also showed a significant reduction of hippocampal atrophy and less expansion of ventricular volume in subjects receiving the multinutrient intervention [122]. In line with previous trials in $\mathrm{AD}$, the LipiDiDiet showed that administration of Souvenaid was well tolerated and had a high rate of adherence $[122,144]$.
Changes from baseline in the levels of uridine, choline, and other nutrients were not reported in the LipiDiDiet study, so it is not possible to correlate effects on clinical and brain imaging endpoints with an improvement in nutritional status. Previous randomized controlled trials in subjects with mild AD showed that Souvenaid increases levels of uridine, choline, DHA, and other key nutrients involved in PC formation [147, 148] and increases markers of phospholipid synthesis in the brain in subjects with mild AD [147]. These findings support the putative mode of action of the product on synapse formation.

At 24 months, there was no difference between groups in progression to dementia; however, preliminary data with long-term (3year) intervention suggests a possible effect favoring multinutrient intervention [144]. Longer-term follow-up of the LipiDiDiet study will provide additional insights into the sustainability of effects observed with multinutrient intervention and hopefully elucidate additional information on which patients are most likely to benefit. It will be interesting to see whether expression of the apolipoprotein $\mathrm{E} 4$ (APOE4) gene modifies the effects of multinutrient intervention in MCI due to AD. APOE4, a major genetic driver of $\mathrm{AD}$, is associated with decreased transport of DHA to the CSF [149] and appears to influence the effects of DHA supplementation in subjects with AD and MCI [138]. In subjects with early-stage $\mathrm{AD}$, the effect of Souvenaid was assessed in predefined subgroups, including expression of the APOE4 genotype; however, no significant effect was observed [141].

Overall, clinical evidence suggests that a specific uridine- and choline-enriched multinutritional intervention may produce meaningful clinical benefits in MCI due to $\mathrm{AD}$, possibly by addressing a conditional shortage in levels of uridine and other key nutrients essential for neuronal membrane formation. Additional studies are needed to extend the findings of the LipiDiDiet study to the presymptomatic stage of $\mathrm{AD}$, and to correlate improvements in nutrient levels with cognitive benefits. 


\section{CONCLUSIONS}

There is strong evidence from systematic reviews and meta-analyses showing a pathologic shortage of uridine and choline in $\mathrm{AD}$, including MCI due to AD, particularly in the levels of these nutrients in the brain or CSF. While the shortfall appears relatively modest, compared with healthy age-matched controls, the impact on the metabolic pathways leading to synapse formation could be significant considering the ongoing loss of synapses that characterizes progression of $\mathrm{MCI}$ and $\mathrm{AD}$. The uridine shortage cannot be corrected simply by modifying a normal diet, making uridine a conditionally essential nutrient in affected individuals. As an essential nutrient, choline must be obtained from the diet; however, correcting the shortfall in individuals with MCI through diet alone is challenging, because brain uptake from the plasma significantly decreases with ageing. Dietary supplements have been used to improve outcomes in subjects with MCI, but there is limited evidence of effectiveness for single-agent supplements and a lack of studies specifically in subjects with MCI due to AD. Preclinical research provides a strong rationale for multinutrient intervention providing supplemental uridine and choline alongside other substrates used in the metabolic pathways for PC formation. Administration of these nutrients at the same time has been shown to increase synapse formation and provide neuroprotection in models of dementia. Clinical trials of a specific multinutrient product containing uridine, choline, and DHA have shown that the benefits are most likely to be achieved at the very early stages of the $\mathrm{AD}$ spectrum, when there is still a possibility to influence the processes affecting synapse formation and loss. To date, there is no evidence that multinutrient intervention can prevent progression of MCI to $\mathrm{AD}$; however, preliminary brain imaging data does suggest an observable slowing of neurodegeneration.

Based on this review, we recommend that nutritional intervention be considered as a part of the personalized approach to the management of individuals with $\mathrm{MCI}$ due to $\mathrm{AD}$, including adherence to a healthy, balanced diet and consideration of evidence-based multinutrient supplements, as indicated. The selection of a multinutritional intervention should be based on strong evidence in a clearly defined population of subjects with MCI.

\section{ACKNOWLEDGEMENTS}

Funding. This manuscript is based on the proceedings of a round table funded by Nutricia and attended by the authors. Nutricia funded the rapid service fee for publication.

Medical Writing and/or Editorial Assistance. Editorial assistance in the preparation of this article was provided by Tim Kelly, MediKelsey Limited. Support for this assistance was funded by Nutricia.

Authorship. All named authors meet the International Committee of Medical Journal Editors (ICMJE) criteria for authorship for this article, take responsibility for the integrity of the work as a whole, and have given their approval for this version to be published.

Disclosures. Barry Baumel, P. Murali Doraiswamy, Marwan Sabbagh, and Richard Wurtman have served as paid advisors to Danone Nutricia. P. Murali Doraiswamy has received research grants and/or advisory/speaking fees from several health and technology companies in this field. P. Murali Doraiswamy owns shares in several companies, whose products are not discussed here. P. Murali Doraiswamy is a coinventor on several patents through Duke University. P. Murali Doraiswamy serves on the boards of several organizations. Marwan Sabbagh has received funding from Brain Health Inc, Harper Collins, NeuroReserve, NeuroTau, Neurotrope, Optimal Cognitive Health Company, uMethod Health, Versanum Inc., Alzheon, Athira, Biogen, Cortexyme, Neurotrope, Regeneron, Roche-Genentech, and Stage 2 Innovations. Richard Wurtman invented the nutrient mixture, which was patented by the 
Massachusetts Institute of Technology and licensed to Danone.

Compliance with Ethics Guidelines. This article is based on previously conducted studies and does not contain any new studies with human participants or animals performed by any of the authors. All clinical trials cited in this review were done in compliance with the Declaration of Helsinki.

Open Access. This article is licensed under a Creative Commons Attribution-NonCommercial 4.0 International License, which permits any non-commercial use, sharing, adaptation, distribution and reproduction in any medium or format, as long as you give appropriate credit to the original author(s) and the source, provide a link to the Creative Commons licence, and indicate if changes were made. The images or other third party material in this article are included in the article's Creative Commons licence, unless indicated otherwise in a credit line to the material. If material is not included in the article's Creative Commons licence and your intended use is not permitted by statutory regulation or exceeds the permitted use, you will need to obtain permission directly from the copyright holder. To view a copy of this licence, visit http://creativecommons.org/licenses/bync/4.0/.

\section{REFERENCES}

1. Albert MS, DeKosky ST, Dickson D, Dubois B, Feldman $\mathrm{HH}$, Fox NC, et al. The diagnosis of mild cognitive impairment due to Alzheimer's disease: recommendations from the National Institute on Aging-Alzheimer's Association workgroups on diagnostic guidelines for Alzheimer's disease. Alzheimers Dement. 2011;7:270-9.

2. Langa KM, Levine DA. The diagnosis and management of mild cognitive impairment: a clinical review. JAMA. 2014;312:2551-61.

3. Dubois B, Feldman HH, Jacova C, Dekosky ST, Barberger-Gateau P, Cummings J, et al. Research criteria for the diagnosis of Alzheimer's disease: revising the NINCDS-ADRDA criteria. Lancet Neurol. 2007;6:734-46.
4. Frisoni GB, Boccardi M, Barkhof F, Blennow K, Cappa S, Chiotis K, et al. Strategic roadmap for an early diagnosis of Alzheimer's disease based on biomarkers. Lancet Neurol. 2017;16:661-76.

5. Petersen RC, Lopez O, Armstrong MJ, Getchius TSD, Ganguli M, Gloss D, et al. Practice guideline update summary: mild cognitive impairment: report of the Guideline Development, Dissemination, and Implementation Subcommittee of the American Academy of Neurology. Neurology. 2018;90: 126-35.

6. Sperling RA, Aisen PS, Beckett LA, Bennett DA, Craft $S$, Fagan AM, et al. Toward defining the preclinical stages of Alzheimer's disease: recommendations from the National Institute on Aging-Alzheimer's Association workgroups on diagnostic guidelines for Alzheimer's disease. Alzheimers Dement. 2011;7:280-92.

7. de Wilde MC, Overk CR, Sijben JW, Masliah E. Meta-analysis of synaptic pathology in Alzheimer's disease reveals selective molecular vesicular machinery vulnerability. Alzheimers Dement. 2016;12:633-44.

8. Livingston G, Sommerlad A, Orgeta V, Costafreda SG, Huntley J, Ames D, et al. Dementia prevention, intervention, and care. Lancet. 2017;390:2673-734.

9. Livingston G, Huntley J, Sommerlad A, Ames D, Ballard C, Banerjee S, et al. Dementia prevention, intervention, and care: 2020 report of the Lancet Commission. Lancet. 2020;396:413-46.

10. Sun MK, Alkon DL. Neuro-regeneration therapeutic for Alzheimer's dementia: perspectives on neurotrophic activity. Trends Pharmacol Sci. 2019;40: 655-68.

11. Canter RG, Penney J, Tsai LH. The road to restoring neural circuits for the treatment of Alzheimer's disease. Nature. 2016;539:187-96.

12. Chen Y, Fu AKY, Ip NY. Synaptic dysfunction in Alzheimer's disease: mechanisms and therapeutic strategies. Pharmacol Ther. 2019;195:186-98.

13. Jackson J, Jambrina E, Li J, Marston H, Menzies F, Phillips K, Gilmour G. Targeting the synapse in Alzheimer's disease. Front Neurosci. 2019;13:735.

14. Skaper SD, Facci L, Zusso M, Giusti P. Synaptic plasticity, dementia and Alzheimer disease. CNS Neurol Disord Drug Targets. 2017;16:220-33.

15. Wurtman RJ. Synapse formation in the brain can be enhanced by co-administering three specific nutrients. Eur J Pharmacol. 2017;817:20-1. 
16. Gibellini F, Smith TK. The Kennedy pathway-de novo synthesis of phosphatidylethanolamine and phosphatidylcholine. IUBMB Life. 2010;62:414-28.

17. Wurtman RJ, Cansev M, Sakamoto T, Ulus IH. Use of phosphatide precursors to promote synaptogenesis. Annu Rev Nutr. 2009;29:59-87.

18. Dobolyi A, Juhasz G, Kovacs Z, Kardos J. Uridine function in the central nervous system. Curr Top Med Chem. 2011;11:1058-67.

19. Vlachos GS, Scarmeas N. Dietary interventions in mild cognitive impairment and dementia. Dialogues Clin Neurosci. 2019;21:69-82.

20. Scarmeas N, Anastasiou CA, Yannakoulia M. Nutrition and prevention of cognitive impairment. Lancet Neurol. 2018;17:1006-15.

21. Solfrizzi V, Custodero C, Lozupone M, Imbimbo BP, Valiani V, Agosti P, et al. Relationships of dietary patterns, foods, and micro- and macronutrients with Alzheimer's disease and late-life cognitive disorders: a systematic review. J Alzheimers Dis. 2017;59:815-49.

22. Kane RL, Butler M, Fink HA, Brasure M, Davila H, Desai P, et al. (2017) Interventions to prevent agerelated cognitive decline, mild cognitive impairment, and clinical Alzheimer's-type dementia. Comparative Effectiveness Review No. 188. AHRQ Publication No. 17-EHC008-EF. Rockville, MD: Agency for Healthcare Research and Quality

23. Jacobson KA, Delicado EG, Gachet C, Kennedy C, von Kugelgen I, Li B, et al. Update of P2Y receptor pharmacology: IUPHAR review 27. Br J Pharmacol. 2020;177:2413-33.

24. von Kugelgen I, Hoffmann K. Pharmacology and structure of P2Y receptors. Neuropharmacology. 2016;104:50-61.

25. Cieslak M, Wojtczak A. Role of purinergic receptors in the Alzheimer's disease. Purinergic Signal. 2018;14:331-44.

26. Connolly GP. Abnormal pyrimidine metabolism is the basis of some neurological diseases. Trends Pharmacol Sci. 1998;19:252.

27. Bekdash RA. Neuroprotective effects of choline and other methyl donors. Nutrients. 2019;11:2995.

28. Blusztajn JK, Slack BE, Mellott TJ. Neuroprotective actions of dietary choline. Nutrients. 2017;9:815.

29. Hampel H, Mesulam MM, Cuello AC, Khachaturian AS, Vergallo A, Farlow MR, et al. Revisiting the cholinergic hypothesis in Alzheimer's disease: emerging evidence from translational and clinical research. J Prev Alzheimers Dis. 2019;6:2-15.

30. Hampel H, Mesulam MM, Cuello AC, Farlow MR, Giacobini E, Grossberg GT, et al. The cholinergic system in the pathophysiology and treatment of Alzheimer's disease. Brain. 2018;141:1917-33.

31. Haense C, Kalbe E, Herholz K, Hohmann C, Neumaier B, Krais R, Heiss WD. Cholinergic system function and cognition in mild cognitive impairment. Neurobiol Aging. 2012;33:867-77.

32. DeKosky ST, Ikonomovic MD, Styren SD, Beckett L, Wisniewski S, Bennett DA, et al. Upregulation of choline acetyltransferase activity in hippocampus and frontal cortex of elderly subjects with mild cognitive impairment. Ann Neurol. 2002;51: 145-55.

33. Arvanitakis Z, Shah RC, Bennett DA. Diagnosis and management of dementia: review. JAMA. 2019;322: 1589-99.

34. Fagone P, Jackowski S. Phosphatidylcholine and the CDP-choline cycle. Biochim Biophys Acta. 2013;1831:523-32.

35. Vance DE. Phospholipid methylation in mammals: from biochemistry to physiological function. Biochim Biophys Acta. 2014;1838:1477-87.

36. Farooqui AA, Rapoport SI, Horrocks LA. Membrane phospholipid alterations in Alzheimer's disease: deficiency of ethanolamine plasmalogens. Neurochem Res. 1997;22:523-7.

37. Ginsberg L, Rafique S, Xuereb JH, Rapoport SI, Gershfeld NL. Disease and anatomic specificity of ethanolamine plasmalogen deficiency in Alzheimer's disease brain. Brain Res. 1995;698:223-6.

38. Gottfries CG, Karlsson I, Svennerholm L. Membrane components separate early-onset Alzheimer's disease from senile dementia of the Alzheimer type. Int Psychogeriatr. 1996;8:365-72.

39. Grimm MO, Grosgen S, Riemenschneider M, Tanila H, Grimm HS, Hartmann T. From brain to food: analysis of phosphatidylcholins, lyso-phosphatidylcholins and phosphatidylcholin-plasmalogens derivates in Alzheimer's disease human post mortem brains and mice model via mass spectrometry. J Chromatogr A. 2011;1218:7713-22.

40. Grimm MO, Kuchenbecker J, Rothhaar TL, Grosgen S, Hundsdorfer B, Burg VK, et al. Plasmalogen synthesis is regulated via alkyl-dihydroxyacetonephosphate-synthase by amyloid precursor protein processing and is affected in Alzheimer's disease. J Neurochem. 2011;116:916-25. 
41. Guan ZZ, Wang YN, Xiao KQ, Hu PS, Liu JL. Activity of phosphatidylethanolamine-N-methyltransferase in brain affected by Alzheimer's disease. Neurochem Int. 1999;34:41-7.

42. Han X, Holtzman DM, McKeel DW Jr. Plasmalogen deficiency in early Alzheimer's disease subjects and in animal models: molecular characterization using electrospray ionization mass spectrometry. J Neurochem. 2001;77:1168-80.

43. Igarashi M, Ma K, Gao F, Kim HW, Rapoport SI, Rao JS. Disturbed choline plasmalogen and phospholipid fatty acid concentrations in Alzheimer's disease prefrontal cortex. J Alzheimers Dis. 2011;24: 507-17.

44. Kou J, Kovacs GG, Hoftberger R, Kulik W, Brodde A, Forss-Petter S, et al. Peroxisomal alterations in Alzheimer's disease. Acta Neuropathol. 2011;122: 271-83.

45. Miatto O, Gonzalez RG, Buonanno F, Growdon JH. In vitro 31P NMR spectroscopy detects altered phospholipid metabolism in Alzheimer's disease. Can J Neurol Sci. 1986;13:535-9.

46. Nitsch RM, Blusztajn JK, Pittas AG, Slack BE, Growdon JH, Wurtman RJ. Evidence for a membrane defect in Alzheimer disease brain. Proc Natl Acad Sci USA. 1992;89:1671-5.

47. Pettegrew JW, Panchalingam K, Hamilton RL, McClure RJ. Brain membrane phospholipid alterations in Alzheimer's disease. Neurochem Res. 2001;26:771-82.

48. Prasad MR, Lovell MA, Yatin M, Dhillon $H$, Markesbery WR. Regional membrane phospholipid alterations in Alzheimer's disease. Neurochem Res. 1998;23:81-8.

49. Wood PL, Barnette BL, Kaye JA, Quinn JF, Woltjer RL. Non-targeted lipidomics of CSF and frontal cortex grey and white matter in control, mild cognitive impairment, and Alzheimer's disease subjects. Acta Neuropsychiatr. 2015;27:270-8.

50. Wood PL, Medicherla S, Sheikh N, Terry B, Phillipps A, Kaye JA, et al. Targeted 1 (lipidomics) of frontal cortex and plasma diacylglycerols (DAG) in mild cognitive impairment and Alzheimer's disease: validation of DAG accumulation early in the pathophysiology of Alzheimer's disease. J Alzheimers Dis. 2015;48:537-46.

51. Fonteh AN, Chiang J, Cipolla M, Hale J, Diallo F, Chirino A, et al. Alterations in cerebrospinal fluid glycerophospholipids and phospholipase A2 activity in Alzheimer's disease. J Lipid Res. 2013;54: 2884-97.
52. Mulder C, Wahlund LO, Teerlink T, Blomberg M, Veerhuis R, van Kamp GJ, et al. Decreased lysophosphatidylcholine/phosphatidylcholine ratio in cerebrospinal fluid in Alzheimer's disease. J Neural Transm (Vienna). 2003;110:949-55.

53. Mulder M, Ravid R, Swaab DF, de Kloet ER, Haasdijk ED, Julk J, et al. Reduced levels of cholesterol, phospholipids, and fatty acids in cerebrospinal fluid of Alzheimer disease patients are not related to apolipoprotein E4. Alzheimer Dis Assoc Disord. 1998;12:198-203.

54. Casanova R, Varma S, Simpson B, Kim M, An Y, Saldana $S$, et al. Blood metabolite markers of preclinical Alzheimer's disease in two longitudinally followed cohorts of older individuals. Alzheimers Dement. 2016;12:815-22.

55. Fiandaca MS, Zhong $\mathrm{X}$, Cheema AK, Orquiza $\mathrm{MH}$, Chidambaram S, Tan MT, et al. Plasma 24-metabolite panel predicts preclinical transition to clinical stages of Alzheimer's disease. Front Neurol. 2015;6: 237.

56. Gonzalez-Dominguez R, Garcia-Barrera T, GomezAriza JL. Combination of metabolomic and phospholipid-profiling approaches for the study of Alzheimer's disease. J Proteomics. 2014;104:37-47.

57. Gonzalez-Dominguez R, Garcia-Barrera T, GomezAriza JL. Metabolomic study of lipids in serum for biomarker discovery in Alzheimer's disease using direct infusion mass spectrometry. J Pharm Biomed Anal. 2014;98:321-6.

58. Gonzalez-Dominguez R, Ruperez FJ, Garcia-Barrera T, Barbas C, Gomez-Ariza JL. Metabolomic-driven elucidation of serum disturbances associated with Alzheimer's disease and mild cognitive impairment. Curr Alzheimer Res. 2016;13:641-53.

59. Goodenowe DB, Cook LL, Liu J, Lu Y, Jayasinghe DA, Ahiahonu PW, et al. Peripheral ethanolamine plasmalogen deficiency: a logical causative factor in Alzheimer's disease and dementia. J Lipid Res. 2007;48:2485-98.

60. Klavins K, Koal T, Dallmann G, Marksteiner J, Kemmler G, Humpel C. The ratio of phosphatidylcholines to lysophosphatidylcholines in plasma differentiates healthy controls from patients with Alzheimer's disease and mild cognitive impairment. Alzheimers Dement (Amst). 2015;1:295-302.

61. Li D, Misialek JR, Boerwinkle E, Gottesman RF, Sharrett AR, Mosley TH, et al. Plasma phospholipids and prevalence of mild cognitive impairment and/ or dementia in the ARIC Neurocognitive Study (ARIC-NCS). Alzheimers Dement (Amst). 2016;3: 73-82. 
62. Li D, Misialek JR, Boerwinkle E, Gottesman RF, Sharrett AR, Mosley TH, et al. Prospective associations of plasma phospholipids and mild cognitive impairment/dementia among African Americans in the ARIC Neurocognitive Study. Alzheimers Dement (Amst). 2017;6:1-10.

63. Mapstone M, Cheema AK, Fiandaca MS, Zhong X, Mhyre TR, MacArthur LH, et al. Plasma phospholipids identify antecedent memory impairment in older adults. Nat Med. 2014;20:415-8.

64. Mapstone M, Lin F, Nalls MA, Cheema AK, Singleton AB, Fiandaca MS, Federoff HJ. What success can teach us about failure: the plasma metabolome of older adults with superior memory and lessons for Alzheimer's disease. Neurobiol Aging. 2017;51: 148-55.

65. Olazaran J, Gil-de-Gomez L, Rodriguez-Martin A, Valenti-Soler M, Frades-Payo B, Marin-Munoz J, et al. A blood-based, 7-metabolite signature for the early diagnosis of Alzheimer's disease. J Alzheimers Dis. $2015 ; 45: 1157-73$.

66. Oresic M, Hyotylainen T, Herukka SK, Sysi-Aho M, Mattila I, Seppanan-Laakso T, et al. Metabolome in progression to Alzheimer's disease. Transl Psychiatry. 2011;1:e57.

67. Proitsi P, Kim M, Whiley L, Simmons A, Sattlecker M, Velayudhan L, et al. Association of blood lipids with Alzheimer's disease: a comprehensive lipidomics analysis. Alzheimers Dement. 2017;13: 140-51.

68. Toledo JB, Arnold M, Kastenmuller G, Chang R, Baillie RA, Han X, et al. Metabolic network failures in Alzheimer's disease: a biochemical road map. Alzheimers Dement. 2017;13:965-84.

69. Whiley L, Sen A, Heaton J, Proitsi P, Garcia-Gomez D, Leung R, et al. Evidence of altered phosphatidylcholine metabolism in Alzheimer's disease. Neurobiol Aging. 2014;35:271-8.

70. Wood PL, Mankidy R, Ritchie S, Heath D, Wood JA, Flax J, Goodenowe DB. Circulating plasmalogen levels and Alzheimer Disease Assessment ScaleCognitive scores in Alzheimer patients. J Psychiatry Neurosci. 2010;35:59-62.

71. Pena-Bautista C, Roca M, Hervas D, Cuevas A, Lopez-Cuevas R, Vento M, et al. Plasma metabolomics in early Alzheimer's disease patients diagnosed with amyloid biomarker. J Proteomics. 2019;200:144-52.

72. Costa AC, Joaquim HPG, Forlenza O, Talib LL, Gattaz WF. Plasma lipids metabolism in mild cognitive impairment and Alzheimer's disease. World J Biol Psychiatry. 2019;20:190-6.
73. Iuliano L, Pacelli A, Ciacciarelli M, Zerbinati C, Fagioli S, Piras F, et al. Plasma fatty acid lipidomics in amnestic mild cognitive impairment and Alzheimer's disease. J Alzheimers Dis. 2013;36:545-53.

74. Selley ML. A metabolic link between S-adenosylhomocysteine and polyunsaturated fatty acid metabolism in Alzheimer's disease. Neurobiol Aging. 2007;28:1834-9.

75. Heude B, Ducimetiere P, Berr C, Study EVA. Cognitive decline and fatty acid composition of erythrocyte membranes-The EVA Study. Am J Clin Nutr. 2003;77:803-8.

76. Tan ZS, Harris WS, Beiser AS, Au R, Himali JJ, Debette $S$, et al. Red blood cell omega-3 fatty acid levels and markers of accelerated brain aging. Neurology. 2012;78:658-64.

77. Schaefer EJ, Bongard V, Beiser AS, Lamon-Fava S, Robins SJ, Au R, et al. Plasma phosphatidylcholine docosahexaenoic acid content and risk of dementia and Alzheimer disease: the Framingham Heart Study. Arch Neurol. 2006;63:1545-50.

78. de Wilde MC, Vellas B, Girault E, Yavuz AC, Sijben JW. Lower brain and blood nutrient status in Alzheimer's disease: results from meta-analyses. Alzheimers Dement. 2017;3:416-31.

79. Lopes da Silva S, Vellas B, Elemans S, Luchsinger J, Kamphuis P, Yaffe K, et al. Plasma nutrient status of patients with Alzheimer's disease: systematic review and meta-analysis. Alzheimers Dement. 2014;10: 485-502.

80. Czech C, Berndt P, Busch K, Schmitz O, Wiemer J, Most $\mathrm{V}$, et al. Metabolite profiling of Alzheimer's disease cerebrospinal fluid. PLoS ONE. 2012;7: e31501.

81. Ibanez C, Simo C, Barupal DK, Fiehn O, Kivipelto M, Cedazo-Minguez A, Cifuentes A. A new metabolomic workflow for early detection of Alzheimer's disease. J Chromatogr A. 2013;1302:65-71.

82. Olde Rikkert MG, Verhey FR, Sijben JW, Bouwman FH, Dautzenberg PL, Lansink M, et al. Differences in nutritional status between very mild Alzheimer's disease patients and healthy controls. J Alzheimers Dis. 2014;41:261-71.

83. van Wijk N, Slot RER, Duits FH, Strik M, Biesheuvel E, Sijben JWC, et al. Nutrients required for phospholipid synthesis are lower in blood and cerebrospinal fluid in mild cognitive impairment and Alzheimer's disease dementia. Alzheimers Dement (Amst). 2017;8:139-46.

84. Wang G, Zhou Y, Huang FJ, Tang HD, Xu XH, Liu JJ, et al. Plasma metabolite profiles of Alzheimer's 
disease and mild cognitive impairment. J Proteome Res. 2014;13:2649-58.

85. Xu J, Begley P, Church SJ, Patassini S, Hollywood KA, Jullig M, et al. Graded perturbations of metabolism in multiple regions of human brain in Alzheimer's disease: snapshot of a pervasive metabolic disorder. Biochim Biophys Acta. 2016;1862: 1084-92.

86. Tsuruoka M, Hara J, Hirayama A, Sugimoto M, Soga T, Shankle WR, Tomita M. Capillary electrophoresis-mass spectrometry-based metabolome analysis of serum and saliva from neurodegenerative dementia patients. Electrophoresis. 2013;34: 2865-72.

87. Graham SF, Chevallier OP, Elliott CT, Holscher C, Johnston J, McGuinness B, et al. Untargeted metabolomic analysis of human plasma indicates differentially affected polyamine and L-arginine metabolism in mild cognitive impairment subjects converting to Alzheimer's disease. PLoS ONE. 2015;10:e0119452.

88. Trushina E, Dutta T, Persson XM, Mielke MM, Petersen RC. Identification of altered metabolic pathways in plasma and CSF in mild cognitive impairment and Alzheimer's disease using metabolomics. PLoS ONE. 2013;8:e63644.

89. Pena-Bautista C, Flor L, Lopez-Nogueroles M, Garcia L, Ferrer I, Baquero M, et al. Plasma alterations in cholinergic and serotonergic systems in early Alzheimer Disease: diagnosis utility. Clin Chim Acta. 2020;500:233-40.

90. Inazu M. Functional expression of choline transporters in the blood-brain barrier. Nutrients. $2019 ; 11: 2265$.

91. Cohen BM, Renshaw PF, Stoll AL, Wurtman RJ, Yurgelun-Todd D, Babb SM. Decreased brain choline uptake in older adults. An in vivo proton magnetic resonance spectroscopy study. JAMA. 1995;274:902-7.

92. Nurk E, Refsum H, Bjelland I, Drevon CA, Tell GS, Ueland PM, et al. Plasma free choline, betaine and cognitive performance: the Hordaland Health Study. Br J Nutr. 2013;109:511-9.

93. Goldberg E, Kindilien S, Roberts M, Cohen D. Working memory and inadequate micronutrient consumption in healthy seniors. J Nutr Gerontol Geriatr. 2019;38:247-61.

94. de Leeuw FA, Tijms BM, Hendriksen HMA, van de Rest $\mathrm{O}$, de van der Schueren MAE, Visser $M$, et al. (2020) LDL cholesterol and uridine levels in blood are potential nutritional markers of $\mathrm{AD}$ progression; the NUDAD project. Alzheimer's Association
International Conference 2020, July 27-31; available online at https://alz.confex.com/alz/ 20amsterdam/meetingapp.cgi/Paper/43108

95. van Wijk N, Broersen LM, de Wilde MC, Hageman RJ, Groenendijk M, Sijben JW, Kamphuis PJ. Targeting synaptic dysfunction in Alzheimer's disease by administering a specific nutrient combination. J Alzheimers Dis. 2014;38:459-79.

96. Cansev M, van Wijk N, Turkyilmaz M, Orhan F, Sijben JW, Broersen LM. Specific multi-nutrient enriched diet enhances hippocampal cholinergic transmission in aged rats. Neurobiol Aging. 2015;36:344-51.

97. Savelkoul P, Merkes M, Kuipers A, Hageman R, Broersen L, Kamphuis P. P4-258: Multi-nutrient supplementation induces changes in synaptic protein expression. Alzheimers Dement. 2011;7:S796-S.

98. van Deijk AF, Broersen LM, Verkuyl JM, Smit AB, Verheijen MHG. High content analysis of hippocampal neuron-astrocyte co-cultures shows a positive effect of Fortasyn Connect on neuronal survival and postsynaptic maturation. Front Neurosci. 2017;11:440.

99. Pooler AM, Guez DH, Benedictus R, Wurtman RJ. Uridine enhances neurite outgrowth in nerve growth factor-differentiated PC12 [corrected]. Neuroscience. 2005;134:207-14.

100. Sakamoto T, Cansev M, Wurtman RJ. Oral supplementation with docosahexaenoic acid and uridine5'-monophosphate increases dendritic spine density in adult gerbil hippocampus. Brain Res. 2007;1182:50-9.

101. Savelkoul P, Lotstra S, Kuipers A, Kamphuis P, Broersen L. P2-043: Combined nutrient supplementation enhances neurite outgrowth and synaptic protein expression in vitro. Alzheimers Dement. 2013;9:P359-60.

102. Wang L, Pooler AM, Albrecht MA, Wurtman RJ. Dietary uridine-5'-monophosphate supplementation increases potassium-evoked dopamine release and promotes neurite outgrowth in aged rats. J Mol Neurosci. 2005;27:137-45.

103. de Wilde MC, Penke B, van der Beek EM, Kuipers AA, Kamphuis PJ, Broersen LM. Neuroprotective effects of a specific multi-nutrient intervention against Abeta42-induced toxicity in rats. J Alzheimers Dis. 2011;27:327-39.

104. Janickova H, Rudajev V, Dolejsi E, Koivisto $H$, Jakubik J, Tanila H, et al. Lipid-based diets improve muscarinic neurotransmission in the hippocampus of transgenic APPswe/PS1dE9 Mice. Curr Alzheimer Res. 2015;12:923-31. 
105. Savelkoul PJ, Janickova H, Kuipers AA, Hageman RJ, Kamphuis PJ, Dolezal V, Broersen LM. A specific multi-nutrient formulation enhances M1 muscarinic acetylcholine receptor responses in vitro. J Neurochem. 2012;120:631-40.

106. Jansen D, Zerbi V, Arnoldussen IA, Wiesmann M, Rijpma A, Fang XT, et al. Effects of specific multinutrient enriched diets on cerebral metabolism, cognition and neuropathology in AbetaPPswePS1dE9 mice. PLoS ONE. 2013;8:e75393.

107. Jansen D, Zerbi V, Janssen CI, van Rooij D, Zinnhardt $\mathrm{B}$, Dederen PJ, et al. Impact of a multi-nutrient diet on cognition, brain metabolism, hemodynamics, and plasticity in apoE4 carrier and apoE knockout mice. Brain Struct Funct. 2014;219: 1841-68.

108. Koivisto H, Grimm MO, Rothhaar TL, Berkecz R, Lutjohann DD, Giniatullina R, et al. Special lipidbased diets alleviate cognitive deficits in the APPswe/PS1dE9 transgenic mouse model of Alzheimer's disease independent of brain amyloid deposition. J Nutr Biochem. 2014;25:157-69.

109. Wiesmann M, Jansen D, Zerbi V, Broersen LM, Garthe A, Kiliaan AJ. Improved spatial learning strategy and memory in aged Alzheimer AbetaPPswe/PS1dE9 mice on a multi-nutrient diet. J Alzheimers Dis. 2013;37:233-45.

110. Broersen LM, Kuipers AA, Balvers M, van Wijk N, Savelkoul PJ, de Wilde MC, et al. A specific multinutrient diet reduces Alzheimer-like pathology in young adult AbetaPPswe/PS1dE9 mice. J Alzheimers Dis. 2013;33:177-90.

111. Agarwal N, Sung YH, Jensen JE, daCunha G, Harper D, Olson D, Renshaw PF. Short-term administration of uridine increases brain membrane phospholipid precursors in healthy adults: a 31-phosphorus magnetic resonance spectroscopy study at $4 \mathrm{~T}$. Bipolar Disord. 2010;12:825-33.

112. Silveri MM, Dikan J, Ross AJ, Jensen JE, Kamiya T, Kawada Y, et al. Citicoline enhances frontal lobe bioenergetics as measured by phosphorus magnetic resonance spectroscopy. NMR Biomed. 2008;21: 1066-75.

113. Wurtman RJ, Regan M, Ulus I, Yu L. Effect of oral CDP-choline on plasma choline and uridine levels in humans. Biochem Pharmacol. 2000;60:989-92.

114. Spiers PA, Myers D, Hochanadel GS, Lieberman HR, Wurtman RJ. Citicoline improves verbal memory in aging. Arch Neurol. 1996;53:441-8.

115. Poly C, Massaro JM, Seshadri S, Wolf PA, Cho E, Krall E, et al. The relation of dietary choline to cognitive performance and white-matter hyperintensity in the Framingham Offspring Cohort. Am J Clin Nutr. 2011;94:1584-91.

116. Ylilauri MPT, Voutilainen S, Lonnroos E, Virtanen HEK, Tuomainen TP, Salonen JT, Virtanen JK. Associations of dietary choline intake with risk of incident dementia and with cognitive performance: the Kuopio Ischaemic Heart Disease Risk Factor Study. Am J Clin Nutr. 2019;110:1416-23.

117. Moreno MDJM. Cognitive improvement in mild to moderate Alzheimer's dementia after treatment with the acetylcholine precursor choline alfoscerate: a multicenter, double-blind, randomized, placebo-controlled trial. Clin Ther. 2003;25:178-93.

118. Lehtisalo J, Ngandu T, Valve P, Antikainen R, Laatikainen T, Strandberg T, et al. Nutrient intake and dietary changes during a 2-year multi-domain lifestyle intervention among older adults: secondary analysis of the Finnish Geriatric Intervention Study to Prevent Cognitive Impairment and Disability (FINGER) randomised controlled trial. Br J Nutr. 2017; 118:291-302.

119. Scarmeas N, Stern Y, Mayeux R, Manly JJ, Schupf N, Luchsinger JA. Mediterranean diet and mild cognitive impairment. Arch Neurol. 2009;66:216-25.

120. Stephen R, Liu Y, Ngandu T, Antikainen R, Hulkkonen J, Koikkalainen J, et al. Brain volumes and cortical thickness on MRI in the Finnish Geriatric Intervention Study to Prevent Cognitive Impairment and Disability (FINGER). Alzheimers Res Ther. 2019;11:53.

121. McGrattan AM, McEvoy CT, McGuinness B, McKinley MC, Woodside JV. Effect of dietary interventions in mild cognitive impairment: a systematic review. Br J Nutr. 2018;120:1388-405.

122. Soininen $H$, Solomon A, Visser PJ, Hendrix SB, Blennow K, Kivipelto M, et al. 24-month intervention with a specific multinutrient in people with prodromal Alzheimer's disease (LipiDiDiet): a randomised, double-blind, controlled trial. Lancet Neurol. 2017;16:965-75.

123. McGrattan AM, McEvoy CT, McGuinness B, McKinley MC, Woodside JV. The effect of diet, lifestyle and/or cognitive interventions in mild cognitive impairment: a systematic review. Proc Nutr Soc. 2017;76:E114.

124. Morris MC, Evans DA, Bienias JL, Tangney CC, Bennett DA, Aggarwal N, et al. Dietary fats and the risk of incident Alzheimer disease. Arch Neurol. 2003;60:194-200.

125. Corrada MM, Kawas CH, Hallfrisch J, Muller D, Brookmeyer R. Reduced risk of Alzheimer's disease 
with high folate intake: the Baltimore Longitudinal Study of Aging. Alzheimers Dement. 2005;1:11-8.

126. Gasser T, Moyer JD, Handschumacher RE. Novel single-pass exchange of circulating uridine in rat liver. Science. 1981;213:777-8.

127. Yamamoto T, Moriwaki Y, Takahashi S, Tsutsumi Z, Ka T, Fukuchi M, Hada T. Effect of beer on the plasma concentrations of uridine and purine bases. Metabolism. 2002;51:1317-23.

128. Wallace TC, Blusztajn JK, Caudill MA, Klatt KC, Natker E, Zeisel SH, Zelman KM. Choline: the underconsumed and underappreciated essential nutrient. Nutr Today. 2018;53:240-53.

129. Morris MC, Evans DA, Bienias JL, Tangney CC, Bennett DA, Wilson RS, et al. Consumption of fish and n-3 fatty acids and risk of incident Alzheimer disease. Arch Neurol. 2003;60:940-6.

130. Zhang Y, Chen J, Qiu J, Li Y, Wang J, Jiao J. Intakes of fish and polyunsaturated fatty acids and mild-tosevere cognitive impairment risks: a dose-response meta-analysis of 21 cohort studies. Am J Clin Nutr. 2016;103:330-40.

131. Freund-Levi Y, Eriksdotter-Jonhagen M, Cederholm T, Basun H, Faxen-Irving G, Garlind A, et al. Omega3 fatty acid treatment in 174 patients with mild to moderate Alzheimer disease: OmegAD study: a randomized double-blind trial. Arch Neurol. 2006;63:1402-8.

132. Quinn JF, Raman R, Thomas RG, Yurko-Mauro K, Nelson EB, Van Dyck C, et al. Docosahexaenoic acid supplementation and cognitive decline in Alzheimer disease: a randomized trial. JAMA. 2010;304: 1903-11.

133. Thal LJ, Rosen W, Sharpless NS, Crystal H. Choline chloride fails to improve cognition of Alzheimer's disease. Neurobiol Aging. 1981;2:205-8.

134. Fisman M, Merskey H, Helmes E, McCready J, Colhoun EH, Rylett BJ. Double blind study of lecithin in patients with Alzheimer's disease. Can J Psychiatry. $1981 ; 26: 426-8$.

135. Engelborghs S, Gilles C, Ivanoiu A, Vandewoude M. Rationale and clinical data supporting nutritional intervention in Alzheimer's disease. Acta Clin Belg. 2014;69:17-24.

136. Andrieu S, Guyonnet S, Coley N, Cantet C, Bonnefoy $\mathrm{M}$, Bordes $\mathrm{S}$, et al. Effect of long-term omega 3 polyunsaturated fatty acid supplementation with or without multidomain intervention on cognitive function in elderly adults with memory complaints (MAPT): a randomised, placebo-controlled trial. Lancet Neurol. 2017;16:377-89.
137. Phillips MA, Childs CE, Calder PC, Rogers PJ. No effect of omega-3 fatty acid supplementation on cognition and mood in individuals with cognitive impairment and probable Alzheimer's disease: a randomised controlled trial. Int J Mol Sci. 2015;16: 24600-13.

138. Yassine HN, Braskie MN, Mack WJ, Castor KJ, Fonteh AN, Schneider LS, et al. Association of docosahexaenoic acid supplementation with Alzheimer disease stage in apolipoprotein $\mathrm{E}$ epsilon 4 carriers: a review. JAMA Neurol. 2017;74:339-47.

139. Grimm MOW, Michaelson DM, Hartmann T. Omega-3 fatty acids, lipids, and apoE lipidation in Alzheimer's disease: a rationale for multi-nutrient dementia prevention. J Lipid Res. 2017;58: 2083-101.

140. Olde Rikkert MG, Verhey FR, Blesa R, von Arnim CA, Bongers A, Harrison J, et al. Tolerability and safety of Souvenaid in patients with mild Alzheimer's disease: results of multi-center, 24-week, open-label extension study. J Alzheimers Dis. 2015;44:471-80.

141. Scheltens P, Kamphuis PJ, Verhey FR, Olde Rikkert MG, Wurtman RJ, Wilkinson D, et al. Efficacy of a medical food in mild Alzheimer's disease: a randomized, controlled trial. Alzheimers Dement. 2010;6(1-10):e1.

142. Scheltens P, Twisk JW, Blesa R, Scarpini E, von Arnim CA, Bongers A, et al. Efficacy of Souvenaid in mild Alzheimer's disease: results from a randomized, controlled trial. J Alzheimers Dis. 2012;31: 225-36.

143. Shah RC, Kamphuis PJ, Leurgans S, Swinkels SH, Sadowsky $\mathrm{CH}$, Bongers A, et al. The S-Connect study: results from a randomized, controlled trial of Souvenaid in mild-to-moderate Alzheimer's disease. Alzheimers Res Ther. 2013;5:59.

144. Soininen H. 36-month LipiDiDiet multinutrient clinical trial in prodromal Alzheimer's disease. Alzheimers Dement. 2020. https://doi.org/10.1002/alz. 12172.

145. Wang J, Logovinsky V, Hendrix SB, Stanworth SH, Perdomo C, $\mathrm{Xu} \mathrm{L}$, et al. ADCOMS: a composite clinical outcome for prodromal Alzheimer's disease trials. J Neurol Neurosurg Psychiatry. 2016;87: 993-9.

146. Hendrix SB, Soininen H, Visser PJ, Solomon A, Kivipelto M, Hartmann T. ADCOMS: a post-hoc analysis using data from the LipiDiDiet trial in prodromal Alzheimer's disease 11th Clinical trials on Alzheimer's Disease; October 24-27, 2018; Barcelona 
147. Rijpma A, Meulenbroek O, van der Graaf M, Lansbergen M, Sijben J, Heerschap A, Rikkert MO. The effect of Souvenaid on brain phospholipid metabolism in patients with mild Alzheimer's disease: results of a randomised controlled 31P-magnetic resonance spectroscopy study. Neurobiol Aging. 2016;39:S7-8.

148. Rijpma A, Meulenbroek O, van Hees AM, Sijben JW, Vellas B, Shah RC, et al. Effects of Souvenaid on plasma micronutrient levels and fatty acid profiles in mild and mild-to-moderate Alzheimer's disease. Alzheimers Res Ther. 2015;7:51.

149. Yassine HN, Rawat V, Mack WJ, Quinn JF, YurkoMauro K, Bailey-Hall E, et al. The effect of APOE genotype on the delivery of DHA to cerebrospinal fluid in Alzheimer's disease. Alzheimers Res Ther. 2016;8:25. 